\title{
Evaluation of groundwater contamination for fluoride and nitrate in Nellore Urban Province, Southern India: a special emphasis on human health risk assessment (HHRA)
}

\author{
C. K. V. Chaithanya Reddy ${ }^{1}$. Veeraswamy Golla ${ }^{1}$ D Pradeep Kumar Badapalli ${ }^{2}$ N. B. Y. Reddy ${ }^{1}$
}

Received: 8 September 2021 / Accepted: 15 November 2021 / Published online: 7 February 2022

(c) The Author(s) 2022

\begin{abstract}
Groundwater pollution with fluoride and nitrate is one of the most serious issues in coastal regions. Thirty-nine groundwater samples were collected in the current research region and tested for PH, TDS, and EC. Thirty-nine groundwater samples were collected in the current research region and tested for PH, TDS, EC and cations, anions, and hardness. The elevated parameters are EC, PH, TDS, and nitrates. The fluoride fell in the permissible limit in Nellore urban area, nitrate and fluoride exposure heath risk calculated by using the US EPA method. From that, the total hazard index (THI) was calculated. The fluoride total hazard index value ranges from 0.15 to 0.95 and that of average 0.45 , which fell below $<1$, hence no significance on children, women, and men. The nitrate is falling in excess in groundwater. The ranges are $35 \mathrm{mg} / 1$ to $72 \mathrm{mg} / 1$, and adverse value is $47.8 \mathrm{mg} / \mathrm{l}$. The total hazard index (THI) of nitrates fell at $>1$, which indicates a harmful for the human health. The computed THI affected percentage is the children (100\%), women (95\%), and men (30\%). The nitrate was released in water due to the industrial discharge, septic tanks, manure pools, sewer system, and rock-water interaction. The abundance of the cations and anions is $\mathrm{Ca}^{2+}>\mathrm{Na}^{+}>\mathrm{Mg}^{2+}>\mathrm{K}^{+}$and $\mathrm{HCO}_{3}{ }^{-}>\mathrm{Cl}^{-}>\mathrm{SO}_{4}{ }^{2}>\mathrm{NO} 3>\mathrm{F}$. The Gibbs diagram explains the source of the chemistry; hence, all samples fell in the rock-water interaction area.
\end{abstract}

Keywords Groundwater · Geochemistry $\cdot$ Nitrate $\cdot$ Fluoride $\cdot$ Total hazard index (THI) And health hazard risk assessment (HHRA)

\section{Introduction}

Groundwater is regarded as a dependable supply of fresh water that is easily available for a variety of human needs, including domestic, industrial, irrigation, fish propagation, and so on. Around 1.5 billion people rely on groundwater for their residential and agricultural needs, either directly or indirectly. However, a number of geogenic pollutants in groundwater have been identified across the world in recent years. Geology, aquifer features, climate, geography, subsurface activities, and different geochemical processes influence groundwater quality (Veeraswamy et al. 2018; Adimalla and

Veeraswamy Golla

veeraswamygolla33@gmail.com

1 Department of Geology, Sri Venkateswara University, Tirupati 517502, India

2 Department of Geology, Yogi Vemana University, Kadapa 516005, India
Qian 2021). Water is a better commodity for the survival of both biotic and abiotic (Golla et al. 2020). Groundwater contamination is exceeding in the urban areas due to the increase in population, urbanization, and industrialization and $80 \%$ of the rural domestic water needs, and 50\% of the urban water needs in India (Sharma 1999; Alimohammadi et al. 2018; Rezvani Ghalhari et al. 2021). During the last few decades, nitrate and fluoride have been one of the burning problems on human health in such as methemoglobinemia, stomach ache and dental, skeletal fluorosis in the developing countries like China and India (Darvishmotevalli et al. 2019; Gevera et al. 2019; Onipe et al. 2020; Aravinthasamy et al. 2020). In urban and rural areas, $80 \%$ of the people rely on groundwater only (Muralidhara Reddy and Sunitha 2020).

Nitrate is a chemical pollutant that may be found in modest concentrations in a variety of settings and is the most common chemical contaminant in the world's aquifers. Because of the heavy use of fertilizers, agricultural runoff, trash dumps, and contamination with human or animal wastes, the amount of nitrate in groundwater 
has grown in the previous three decades. Furthermore, through septic systems and leaky municipal sewers, certain nitrogenous chemicals seep into the groundwater. Nitrate pollution of groundwater has become a significant concern in several Indian states. The source of nitrate was extensively used in agriculture fertilizers, oxidizing agents (Hadi Rezaei et al. 2018), and potassium nitrate which are used for glass making (Mirzaei 2015). In soil, fertilizers containing inorganic nitrogen and wastes containing organic nitrogen are first decomposed to give ammonia, which is then oxidized to nitrite and nitrate (Rahmati et al. 2014; Adimalla et al. 2019). The nitrate is taken up by plants during their growth and used in the synthesis of organic nitrogenous compounds. Surplus nitrate readily moves with the groundwater ( $\mathrm{Yu}$ et al. 2020). Fluoride source, where the hornblende granite schist, mica mineral, apatite, amphibole, and fluorite were available, due to the geogenic influence, rock-water interaction, dissolution process, high residence time, and the groundwater, may be severely polluted (Garg et al. 2009; Narsimha and Sudarshan 2017; Vivian et al. 2019). In the study area, there was no significant effect of fluoride. The study area water is consumed by the people, after completion of purification.

\section{Study area}

The study area is Nellore urban area that lies between north latitudes $14^{\circ} 22^{\prime} 30^{\prime \prime} \mathrm{N}$ and $14^{\circ} 30^{\prime} 00^{\prime \prime} \mathrm{N}$ and longitudes $79^{\circ} 52^{\prime} 00^{\prime \prime} \mathrm{E}$ and $80^{\circ} 02^{\prime} 00^{\prime \prime} \mathrm{E}$ in the south-eastern part of Andhra Pradesh state. Landsat 8 ETM + satellite data was used for the preparation of location map in Fig. 1. The area is covered by a survey of India Toposheet 57 N/15. It is located on the banks of the Penna River in the Nellore revenue division. It is a municipal corporation and the headquarters of the Nellore district. The city is the fourth most populous settlement of the state well-known for its agriculture and aquaculture. Unconsolidated sediments belonging to the quaternary period occur in the area. A small stretch of Dharwar gneiss and schist occurs in the western part. Tertiary sandstone and conglomerate occur below the quaternary sediments. The Dharwars and sandstones are weathered and lateritized. Gneisses, schists, and quartzite's belonging to the Dharwar supergroup occur as small outcrops, inselbergs, and in good sections near Gudur-Sarvepalli road. Biotitemuscovite schist intruded by veins of smoky quartz occurs at Batlapalem (Fig. 2). The rocks exhibit foliation that trends $\mathrm{N} 15^{\circ} \mathrm{W}-\mathrm{S} 15^{\circ} \mathrm{E}$ with steep westerly and easterly

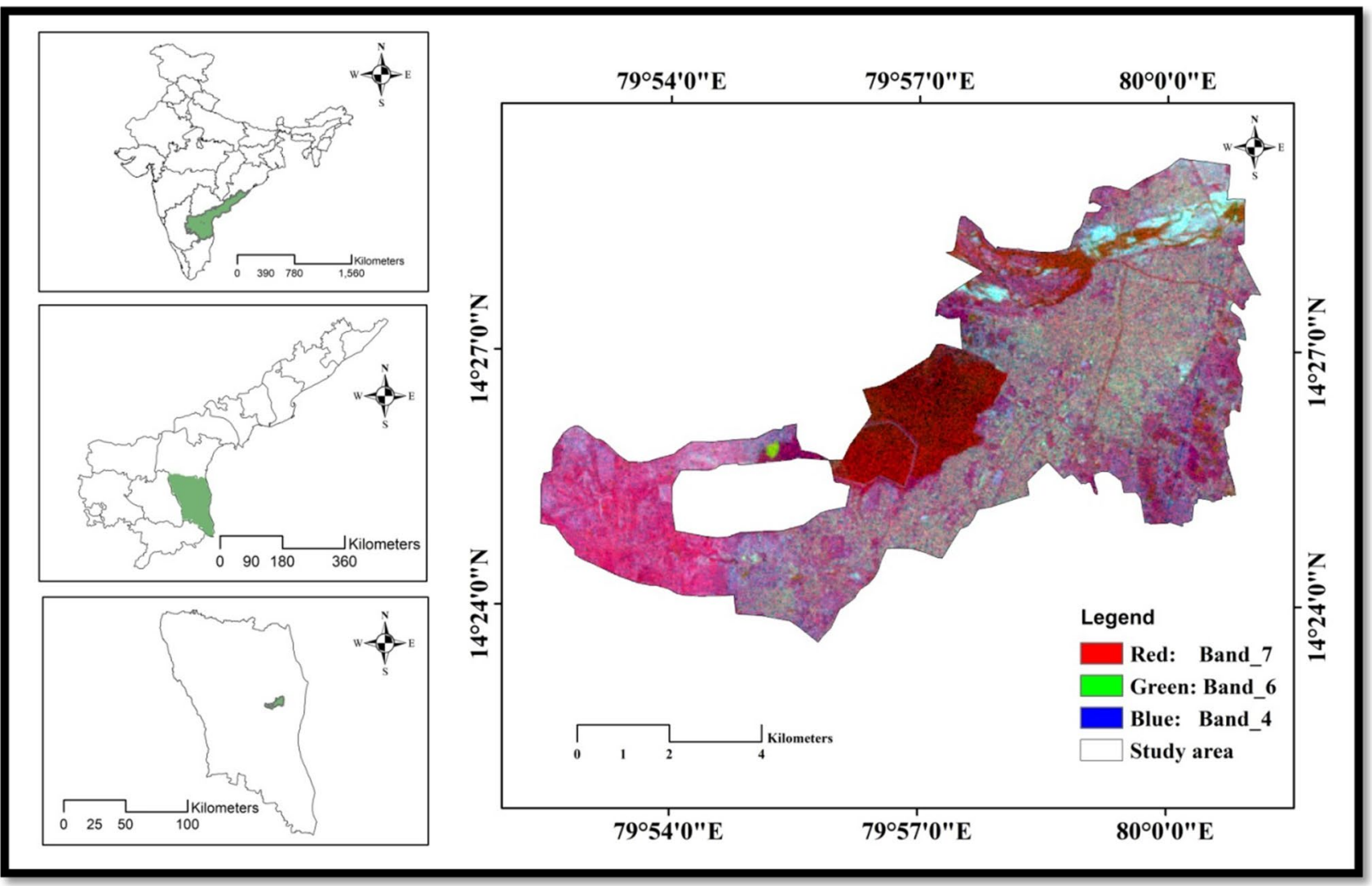

Fig. 1 Location map of the study area 


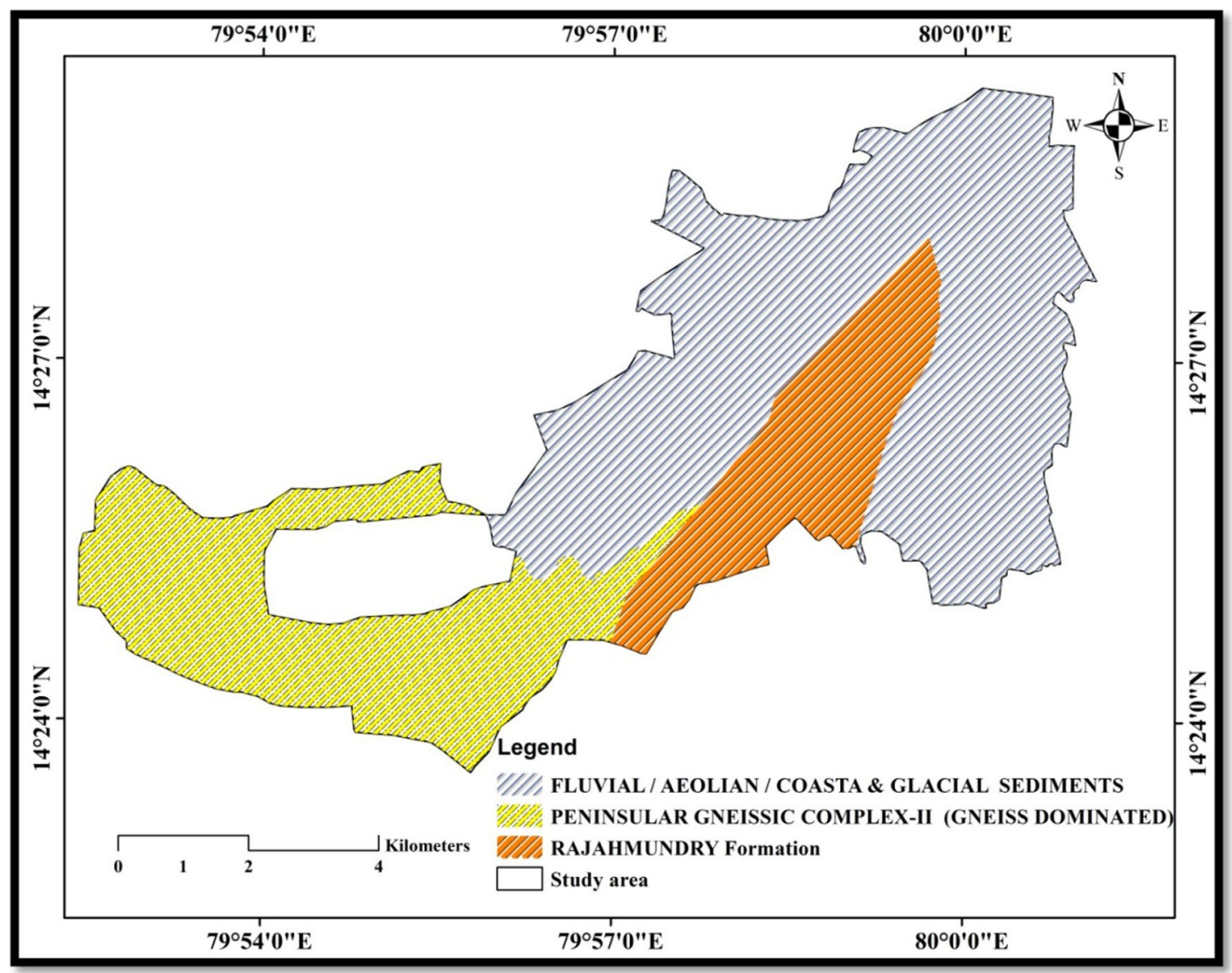

Fig. 2 Geology map of the study area

dip (Nagaraju et al. 2016; Veeraswamy et al. 2018). Tertiary sandstone, consisting of course-to-medium-grained feldspathic sandstone, with low easterly dips, is seen in small sections south of Nellore, Anikepalli, and Kantepalli. The sandstone is overlain by a polymictic conglomerate in a canal cutting west of Sarvepalli and in good sections in the surrounding areas.

\section{Materials and methods}

The study area is Nellore urban area that lies between north latitudes $14^{\circ} 22^{\prime} 30^{\prime \prime} \mathrm{N}$ and $14^{\circ} 30^{\prime} 00^{\prime \prime} \mathrm{N}$ and longitudes $79^{\circ}$ $52^{\prime} 00^{\prime \prime} \mathrm{E}$ and $80^{\circ} 02^{\prime} 00^{\prime \prime} \mathrm{E}$ in the south-eastern part of Andhra Pradesh state (Figs. 1 and 2). The area is covered by a survey of India Toposheet 57 N/15. It is located on the banks of the Penna River in the Nellore revenue division. It is a municipal corporation and the headquarters of the Nellore district (Golla et al. 2020). The city is the fourth most populous settlement of the state well-known for its agriculture and aquaculture. Unconsolidated sediments belonging to the quaternary period occur in the area. A small stretch of Dharwar gneiss and schist occurs in the western part. Tertiary sandstone and conglomerate occur below the quaternary sediments. The Dharwars and sandstones are weathered and lateritized. Gneisses, schists, and quartzite's belonging to the Dharwar supergroup occur as small outcrops, inselbergs, and in good sections near Gudur-Sarvepalli road. Biotite-muscovite schist intruded by veins of smoky quartz occurs at Batlapalem. The rocks exhibit foliation that trends $\mathrm{N} 15^{\circ} \mathrm{W}-\mathrm{S} 15^{\circ} \mathrm{E}$ with steep westerly and easterly dip (Nagaraju et al. 2016; Veeraswamy et al. 2018). Tertiary sandstone, consisting of coarse-to-medium-grained feldspathic sandstone, with low easterly dips, is seen in small sections south of Nellore, Anikepalli, and Kantepalli. The sandstone is overlain by a polymictic conglomerate in a canal cutting west of Sarvepalli and in good sections in the surrounding areas.

\section{Sampling collection}

In Nellore urban area, 39 groundwater samples were collected in one-liter polyethylene bottles; before collecting the water samples, bottles have been cleaned with 5\% nitric 
acid $\mathrm{HNO}_{3}$. All these samples were analyzed in the laboratory for major irons $\left(\mathrm{K}^{++}, \mathrm{Na}^{+}, \mathrm{Ca}^{2+}, \mathrm{Mg}^{2+}, \mathrm{HCO}_{3}^{-}, \mathrm{SO}_{4}{ }^{2-}\right.$, and $\mathrm{Cl}^{-}$), total dissolved solids (TDS), and total hardness (TH). During sample collection, handling, and preservation, standard procedures recommended by the Standard Examination Methods for Drinking Water (BIS 2006 \& ICMR) were followed. Among the analyzed chemical parameters, $\mathrm{Na}+$ and $\mathrm{K}+$ were determined by a flame photometer (GFU2202); $\mathrm{SO}_{4}{ }^{2-}$ and $\mathrm{Cl}^{-}$were analyzed by ion chromatography (HPLC2601); $\mathrm{Ca}^{2+}, \mathrm{Mg}^{2+}, \mathrm{HCO}_{3}{ }^{-}$, and $\mathrm{CO}_{3}{ }^{2-}$ were analyzed by titrimetric method; TDS was determined by the method of drying and weighing; and TH was the sum of $\mathrm{Ca}^{2+}$ and $\mathrm{Mg}^{2+}$ (Table 1) The $\mathrm{pH}$, easily influenced by the external environment, was measured with a portable $\mathrm{pH}$ meter on site.

\section{Result and discussion}

\section{PH}

$\mathrm{P}^{\mathrm{H}}$ means negative logger them of hydrogen ion concentration. $\mathrm{pH}$ scale is 0 to $<7$ for acid, 7 - for neutral, and $>7$ for acidic. In the Nellore urban area, the values range from 7.1 to 9.1 and average is of 8.3. A total of $10 \%$ of the samples were not permissible for drinking, and the remaining fell permissible. $\mathrm{Ph}$ is higher in the rainy season and lower in the dry season and same as in the confined and unconfined aquifer (Agoubi et al. 2013; Petalas and Diamantis 1999; Zhou et al. 2015).

\section{Electrical conductivity (EC)}

It is indicated that electricity passes through media and articulated as microsiemens/cm or micromhos/cm (Nagaraju et al. 2015; Balaji et al. 2017). The EC values range from 400 to.

$2900 \mu \mathrm{S} / \mathrm{cm}$, and average value is $765 \mu \mathrm{S} / \mathrm{cm}$. In the present study area, $81 \%$ of samples fell in the good, $16 \%$ in doubtful, and 3\% in unsuitable (Table 2). The EC values increase in the groundwater due to the dissolution of the mineral content (Jasmin and Mallikarjuna 2013).

\section{Total dissolved solids (TDS)}

The TDS ranges from $260 \mathrm{mg} / \mathrm{l} \mathrm{t} 01885 \mathrm{mg} / \mathrm{l}$ and an average of $497.2 \mathrm{mg} / \mathrm{l}$. A total of $99 \%$ of the samples were falling the fresh according to the Carrol $(1962)<1000 \mathrm{mg} / \mathrm{l}$ and the remaining $1 \%$ fall in the brackish nature $(1000-10000 \mathrm{mg} / \mathrm{l})$ (Monjerezi et al. 2012). Total dissolved solids (TDS) can be attributed mainly due to the addition of ions by weathering and leaching of non-resistant minerals from rocks

Table 2 Classification of electrical conductivity

\begin{tabular}{lll}
\hline Excellent & $<250$ & \\
\hline Good & $250-750$ & $30(81 \%)$ \\
Doubtful & $750-2250$ & $6(16 \%)$ \\
Unsuitable & $>2250$ & $1(3 \%)$ \\
\hline
\end{tabular}

Table 1 Groundwater chemistry of minimum and maximum average values

\begin{tabular}{lllllll}
\hline Parameters & Min & Max & Average & SD & Median & SE \\
\hline $\mathrm{EC}$ & 400 & 2900 & 765 & 459.7 & 650 & 65.02 \\
$\mathrm{pH}$ & 7.1 & 9.7 & 8.3 & 0.8 & 8.1 & 0.11 \\
$\mathrm{TDS}$ & 260 & 1885 & 497.2 & 298.8 & 422.5 & 42.26 \\
$\mathrm{Ca}(\mathrm{mg} / \mathrm{l})$ & 25 & 86 & 45.3 & 13.1 & 40 & 1.86 \\
$\mathrm{Mg}(\mathrm{mg} / \mathrm{l})$ & 10 & 56 & 43.7 & 10.6 & 45 & 1.5 \\
$\mathrm{Na}(\mathrm{mg} / \mathrm{l})$ & 30 & 150 & 75.7 & 31.5 & 70 & 4.45 \\
$\mathrm{~K}(\mathrm{mg} / \mathrm{l})$ & 5 & 10 & 7.9 & 2.4 & 10 & 0.34 \\
$\mathrm{HCO}(\mathrm{mg} / \mathrm{l})$ & 50 & 336 & 189 & 78.9 & 215 & 11.15 \\
$\mathrm{~F}(\mathrm{mg} / \mathrm{l})$ & 0.1 & 0.63 & 0.3 & 0.2 & 0.3 & 0.02 \\
$\mathrm{CO}(\mathrm{mg} / \mathrm{l})$ & 0 & 0 & 0 & 0 & 0 & 0 \\
$\mathrm{Cl}(\mathrm{mg} / \mathrm{l})$ & 200 & 300 & 240.2 & 17.9 & 240 & 2.53 \\
$\mathrm{SO}(\mathrm{mg} / \mathrm{l})$ & 30 & 75 & 46.1 & 8.8 & 45 & 1.24 \\
$\mathrm{Hardness}$ & 40 & 305 & 148.3 & 73.9 & 145 & 10.45 \\
$\mathrm{No} 3(\mathrm{mg} / \mathrm{l})$ & 35 & 72 & 47.8 & 7.3 & 45 & 1.04 \\
$\mathrm{GR} \mathrm{I}$ & 0.51 & 0.89 & 0.7 & 0.1 & 0.68 & 0.01 \\
$\mathrm{GR} \mathrm{II}$ & 0.41 & 0.73 & 0.59 & 0.1 & 0.61 & 0.01 \\
$\mathrm{EC}$ & 400 & 2900 & 764.97 & 459.75 & 650 & 65.02 \\
\hline
\end{tabular}


(geogenic), although the influence of anthropogenic components prevailing in the study area (Jun et al. 2015).

\section{Total hardness (TH)}

The $\mathrm{TH}$ ranges from $40 \mathrm{mg} / \mathrm{l}$ to $305 \mathrm{mg} / \mathrm{l}$ and an average of $148.3 \mathrm{mg} / \mathrm{l}$. Hardness refers to the combination of calcium $\left(\mathrm{Ca}^{2+}\right)$ and magnesium $\left(\mathrm{Mg}^{2+}\right)$ ions (Subba Rao and Chaudhary 2019). In the present study area, all groundwater samples fell in the $<500 \mathrm{mg} / \mathrm{l}$, and all groundwater samples were within the permissible limit for drinking.

\section{Cations and anions}

The concentrations of $\mathrm{Na}^{+}$and $\mathrm{K}^{+}$in groundwater samples are in the range of 30 to $150 \mathrm{mg} / \mathrm{l}$ and 5 to $10 \mathrm{mg} / \mathrm{l}$, respectively. The concentrations of $\mathrm{Ca}^{2+}$ and $\mathrm{Mg}^{2+}$ are in the range from 25 to $86 \mathrm{mg} / \mathrm{l}$ and 10 to $56 \mathrm{mg} / \mathrm{l}$, respectively. The concentrations of $\mathrm{HCO}^{-}$ions are ranged from 50 to $336 \mathrm{mg} / \mathrm{l}$. The concentration of $\mathrm{Cl}^{-}$and $\mathrm{SO}_{4}{ }^{2-}$ are in the range of 200 to $300 \mathrm{mg} / \mathrm{l}$ and 30 to $75 \mathrm{mg} / \mathrm{l}$, respectively. The abundance of the major ions in groundwater is in the following order: $\mathrm{Ca}^{2+}>\mathrm{Na}^{+}>\mathrm{Mg}^{2+}>\mathrm{K}^{+}$ and $\mathrm{HCO}_{3}{ }^{-}>\mathrm{Cl}^{-}>\mathrm{SO}_{4}{ }^{2}>\mathrm{NO} 3>\mathrm{F}$. The cations $\left(\mathrm{Ca}^{2+}>\mathrm{Na}^{+}>\mathrm{Mg}^{2+}>\mathrm{K}^{+}\right)$were released due to the rock-water interaction and weathering process. The anions $\left(\mathrm{HCO}_{3}{ }^{-}>\mathrm{Cl}^{-}>\mathrm{SO}_{4}{ }^{2}>\mathrm{NO} 3>\mathrm{F}\right)$, chloride released from the household refuse, sulfates released from pesticide and fertilizers, and fluorides released from the disintegration of the hornblende granite schist (Li et al. 2018; Adimalla et al. 2019, Adimalla 2021).

\section{Nitrites and fluoride health hazard risk assessment}

Fluoride and nitrite concentrations were higher in groundwater than in surface water (Shirke et al. 2021). Human health hazard indexes were calculated for both oral and dermal. The pollutant concentration in groundwater $(\mathrm{Cw})$, frequency of exposure (IR) in days/year, groundwater ingestion rate (IR) in L/day, exposure duration (ED), average body weight (BW), average exposure time (AT), and average daily exposure dose via groundwater ingestion $(\mathrm{mg} / \mathrm{kg} /$ day $)$ are calculated as follows:

Intake ingestion $=\frac{C w \times I R \times E F \times E D}{B W \times A T}$

IR (0.7 L/day for children and 1.5 L/day for adults), EF (365 days/year), ED (12 years for children and 30 years for adults), BW $(65,55$, and $18.5 \mathrm{~kg}$ for men, females, and children, respectively), and AT are the standard values for each parameter (4380 days for children and 10,950 days for adults). In the following phase, HQ ingestion is used to estimate fluoride hazards (Eq. 2):

$\mathrm{HQ}$ ingestion $=\frac{\text { Intake }}{\mathrm{RFD}}$

The total hazard index (THI) of non-carcinogenic risk is evaluated (Eq. 3) as follows:

$\mathrm{THI}=\sum_{k=1}^{n} \mathrm{HQ}$ ingestion

Similarly, the average daily exposure dose via dermal contact of groundwater ( $\mathrm{mg} / \mathrm{kg} /$ day) is calculated as follows (Adimalla 2019):

Intake ingestion $=\frac{\mathrm{Cw} \times \mathrm{SA} \times \mathrm{SAF} \times \mathrm{DAF} \times \mathrm{EF} \times \mathrm{ED}}{\mathrm{BW} \times \mathrm{AT}}$

where $\mathrm{Cw}$ is pollutant concentration in groundwater, SA is the exposed skin surface area $(1600 \mathrm{~cm} 2$ for children and $4350 \mathrm{~cm} 2$ for adults), SAF is the skin adherence factor $\left[0.2 \mathrm{mg}\left(\mathrm{cm}^{2}\right.\right.$ day - 1], DAF is the dermal absorption factor $(0.001)$, BW is the average body weight $(70 \mathrm{~kg}$ for adults and $20 \mathrm{~kg}$ for children), and AT is the average time for noncarcinogens (365 days) (Yadav et al. 2018; Adimalla and Qian 2021). The fluoride in study area ranges from 0.1 to $0.63 \mathrm{mg} / \mathrm{l}$ and average values $0.3 \mathrm{mg} / \mathrm{l}$. The concentration of fluoride in drinking water is $<1.50 \mathrm{mg} / \mathrm{l}$ (BIS 2012); meanwhile, $>1.50 \mathrm{mg} / \mathrm{l}$ severely damages dental and skeletal fluorosis (Narsimha and Rajitha 2018. Kundu et al. 2001). In the current study area, the total health hazard index (THI) was calculated at different ages like children, men, and women. There is no significantly affected $(0 \%)$ oral and dermal contact in the study area, i.e., as shown in Table 3. The nitrites in the study area ranges from $35 \mathrm{mg} / \mathrm{l}$ to $75 \mathrm{mg} / \mathrm{l}$, and the average value is $47.8 \mathrm{mg} / \mathrm{l} .>45 \mathrm{mg} / \mathrm{l}$ in drinking water severely affected human beings' health diseases like methemoglobin. The main causes were geogenic influences like the interaction of the water through the aquifer media and fertilizers, biogeochemical processes, and pesticides (Fang et al. 2007). The total hazard index value is $>1$, which severely affects human health (Table 4). In the current study area, $99 \%$ of the samples were exceeding the permissible limit. The total hazard index of the various ages was calculated, and the affected percentages were children (100\%), women (95\%), and men (35\%). 
Table 3 Fluoride total hazard index

\begin{tabular}{|c|c|c|c|c|c|c|c|c|c|}
\hline \multirow[t]{3}{*}{ S.No } & \multicolumn{9}{|l|}{ Fluoride } \\
\hline & \multicolumn{3}{|l|}{ HQ Oral } & \multicolumn{3}{|l|}{ HQ Dermal } & \multicolumn{3}{|l|}{ Thi } \\
\hline & Children & Women & Men & Children & Women & Men & Children & Women & Men \\
\hline 1 & 0.5 & 0.38 & 0.32 & $2.64 \mathrm{E}-03$ & $9.96 \mathrm{E}-04$ & $8.43 \mathrm{E}-04$ & 0.5 & 0.38 & 0.32 \\
\hline 2 & 0.27 & 0.2 & 0.17 & $1.44 \mathrm{E}-03$ & $5.43 \mathrm{E}-04$ & $4.60 \mathrm{E}-04$ & 0.27 & 0.21 & 0.17 \\
\hline 3 & 0.72 & 0.55 & 0.46 & $3.84 \mathrm{E}-03$ & $1.45 \mathrm{E}-03$ & $1.23 \mathrm{E}-03$ & 0.72 & 0.55 & 0.46 \\
\hline 4 & 0.71 & 0.53 & 0.45 & $3.76 \mathrm{E}-03$ & $1.42 \mathrm{E}-03$ & $1.20 \mathrm{E}-03$ & 0.71 & 0.54 & 0.45 \\
\hline 5 & 0.57 & 0.43 & 0.37 & $3.04 \mathrm{E}-03$ & $1.15 \mathrm{E}-03$ & $9.70 \mathrm{E}-04$ & 0.57 & 0.43 & 0.37 \\
\hline 6 & 0.95 & 0.72 & 0.61 & $5.04 \mathrm{E}-03$ & $1.90 \mathrm{E}-03$ & $1.61 \mathrm{E}-03$ & 0.95 & 0.72 & 0.61 \\
\hline 7 & 0.65 & 0.49 & 0.41 & $3.44 \mathrm{E}-03$ & $1.30 \mathrm{E}-03$ & $1.10 \mathrm{E}-03$ & 0.65 & 0.49 & 0.41 \\
\hline 8 & 0.15 & 0.11 & 0.1 & $8.00 \mathrm{E}-04$ & $3.02 \mathrm{E}-04$ & $2.55 \mathrm{E}-04$ & 0.15 & 0.11 & 0.1 \\
\hline 9 & 0.47 & 0.35 & 0.3 & $2.48 \mathrm{E}-03$ & $9.36 \mathrm{E}-04$ & $7.92 \mathrm{E}-04$ & 0.47 & 0.35 & 0.3 \\
\hline 10 & 0.15 & 0.11 & 0.1 & $8.00 \mathrm{E}-04$ & $3.02 \mathrm{E}-04$ & $2.55 \mathrm{E}-04$ & 0.15 & 0.11 & 0.1 \\
\hline 11 & 0.71 & 0.53 & 0.45 & $3.76 \mathrm{E}-03$ & $1.42 \mathrm{E}-03$ & $1.20 \mathrm{E}-03$ & 0.71 & 0.54 & 0.45 \\
\hline 12 & 0.45 & 0.34 & 0.29 & $9.23 \mathrm{E}-05$ & $3.48 \mathrm{E}-05$ & $2.90 \mathrm{E}-05$ & 0.45 & 0.34 & 0.29 \\
\hline 13 & 0.45 & 0.34 & 0.29 & $4.71 \mathrm{E}-05$ & $1.78 \mathrm{E}-05$ & $1.46 \mathrm{E}-05$ & 0.45 & 0.34 & 0.29 \\
\hline 14 & 0.75 & 0.57 & 0.48 & $5.26 \mathrm{E}-05$ & $1.99 \mathrm{E}-05$ & $1.61 \mathrm{E}-05$ & 0.75 & 0.57 & 0.48 \\
\hline 15 & 0.75 & 0.57 & 0.48 & $3.96 \mathrm{E}-05$ & $1.49 \mathrm{E}-05$ & $1.19 \mathrm{E}-05$ & 0.75 & 0.57 & 0.48 \\
\hline 16 & 0.6 & 0.45 & 0.38 & $2.54 \mathrm{E}-05$ & $9.58 \mathrm{E}-06$ & $7.53 \mathrm{E}-06$ & 0.6 & 0.45 & 0.38 \\
\hline 17 & 0.15 & 0.11 & 0.1 & $5.30 \mathrm{E}-06$ & $2.00 \mathrm{E}-06$ & $1.55 \mathrm{E}-06$ & 0.15 & 0.11 & 0.1 \\
\hline 18 & 0.15 & 0.11 & 0.1 & $4.55 \mathrm{E}-06$ & $1.71 \mathrm{E}-06$ & $1.31 \mathrm{E}-06$ & 0.15 & 0.11 & 0.1 \\
\hline 19 & 0.15 & 0.11 & 0.1 & $3.98 \mathrm{E}-06$ & $1.50 \mathrm{E}-06$ & $1.13 \mathrm{E}-06$ & 0.15 & 0.11 & 0.1 \\
\hline 20 & 0.45 & 0.34 & 0.29 & $1.06 \mathrm{E}-05$ & $4.01 \mathrm{E}-06$ & $2.98 \mathrm{E}-06$ & 0.45 & 0.34 & 0.29 \\
\hline 21 & 0.15 & 0.11 & 0.1 & $3.19 \mathrm{E}-06$ & $1.20 \mathrm{E}-06$ & $8.82 \mathrm{E}-07$ & 0.15 & 0.11 & 0.1 \\
\hline 22 & 0.65 & 0.49 & 0.41 & $1.25 \mathrm{E}-05$ & $4.70 \mathrm{E}-06$ & $3.40 \mathrm{E}-06$ & 0.65 & 0.49 & 0.41 \\
\hline 23 & 0.15 & 0.11 & 0.1 & $2.66 \mathrm{E}-06$ & $1.00 \mathrm{E}-06$ & $7.16 \mathrm{E}-07$ & 0.15 & 0.11 & 0.1 \\
\hline 24 & 0.47 & 0.35 & 0.3 & $7.61 \mathrm{E}-06$ & $2.87 \mathrm{E}-06$ & $2.02 \mathrm{E}-06$ & 0.47 & 0.35 & 0.3 \\
\hline 25 & 0.15 & 0.11 & 0.1 & $2.28 \mathrm{E}-06$ & $8.60 \mathrm{E}-07$ & $5.99 \mathrm{E}-07$ & 0.15 & 0.11 & 0.1 \\
\hline 26 & 0.71 & 0.53 & 0.45 & $1.00 \mathrm{E}-05$ & $3.77 \mathrm{E}-06$ & $2.59 \mathrm{E}-06$ & 0.71 & 0.53 & 0.45 \\
\hline 27 & 0.45 & 0.34 & 0.29 & $5.99 \mathrm{E}-06$ & $2.26 \mathrm{E}-06$ & $1.53 \mathrm{E}-06$ & 0.45 & 0.34 & 0.29 \\
\hline 28 & 0.45 & 0.34 & 0.29 & $5.63 \mathrm{E}-06$ & $2.13 \mathrm{E}-06$ & $1.43 \mathrm{E}-06$ & 0.45 & 0.34 & 0.29 \\
\hline 29 & 0.75 & 0.57 & 0.48 & $8.87 \mathrm{E}-06$ & $3.35 \mathrm{E}-06$ & $2.22 \mathrm{E}-06$ & 0.75 & 0.57 & 0.48 \\
\hline 30 & 0.75 & 0.57 & 0.48 & $8.40 \mathrm{E}-06$ & $3.17 \mathrm{E}-06$ & $2.08 \mathrm{E}-06$ & 0.75 & 0.57 & 0.48 \\
\hline 31 & 0.6 & 0.45 & 0.38 & $6.39 \mathrm{E}-06$ & $2.41 \mathrm{E}-06$ & $1.56 \mathrm{E}-06$ & 0.6 & 0.45 & 0.38 \\
\hline 32 & 0.15 & 0.11 & 0.1 & $1.60 \mathrm{E}-06$ & $6.02 \mathrm{E}-07$ & $3.90 \mathrm{E}-07$ & 0.15 & 0.11 & 0.1 \\
\hline 33 & 0.15 & 0.11 & 0.1 & $1.60 \mathrm{E}-06$ & $6.02 \mathrm{E}-07$ & $3.90 \mathrm{E}-07$ & 0.15 & 0.11 & 0.1 \\
\hline 34 & 0.15 & 0.11 & 0.1 & $1.60 \mathrm{E}-06$ & $6.02 \mathrm{E}-07$ & $3.90 \mathrm{E}-07$ & 0.15 & 0.11 & 0.1 \\
\hline 35 & 0.45 & 0.34 & 0.29 & $4.79 \mathrm{E}-06$ & $1.81 \mathrm{E}-06$ & $1.17 \mathrm{E}-06$ & 0.45 & 0.34 & 0.29 \\
\hline 36 & 0.15 & 0.11 & 0.1 & $1.60 \mathrm{E}-06$ & $6.02 \mathrm{E}-07$ & $3.90 \mathrm{E}-07$ & 0.15 & 0.11 & 0.1 \\
\hline 37 & 0.71 & 0.53 & 0.45 & $7.50 \mathrm{E}-06$ & $2.83 \mathrm{E}-06$ & $1.83 \mathrm{E}-06$ & 0.71 & 0.53 & 0.45 \\
\hline Min & 0.15 & 0.11 & 0.1 & 0 & 0 & $3.90 \mathrm{E}-07$ & 0.15 & 0.11 & 0.1 \\
\hline Max & 0.95 & 0.72 & 0.61 & 0.01 & 0 & 0 & 0.95 & 0.72 & 0.61 \\
\hline AVG & 0.45 & 0.34 & 0.29 & 0 & 0 & 0 & 0.45 & 0.34 & 0.29 \\
\hline$\%$ Affected & $0 \%$ & $0 \%$ & $0 \%$ & $0 \%$ & $0 \%$ & $0 \%$ & $0 \%$ & $0 \%$ & $0 \%$ \\
\hline
\end{tabular}

\section{Gibb's diagram}

The ratio of $\mathrm{Na}+/(\mathrm{Na}++\mathrm{Ca} 2+)$ and $\mathrm{Cl} /(\mathrm{Cl}+\mathrm{HCO} 3)$ as a function of TDS is represented by a Gibbs diagram, which is frequently used to evaluate the functional sources of dissolved chemical components, such as precipitation dominance, rock dominance, and evaporation dominance. Water chemistry is evolved as a result of water-rock interaction 
Table 4 Nitrate total hazard index

\begin{tabular}{|c|c|c|c|c|c|c|c|c|c|}
\hline \multirow[t]{3}{*}{ S.No } & \multicolumn{9}{|l|}{ Nitrate } \\
\hline & \multicolumn{3}{|l|}{ HQ Oral } & \multicolumn{3}{|l|}{ HQ Dermal } & \multicolumn{3}{|l|}{ Thi } \\
\hline & Children & Women & Men & Children & Women & Men & Children & Women & Men \\
\hline 1 & 3.09 & 1.43 & 1.07 & $1.10 \mathrm{E}-02$ & $4.15 \mathrm{E}-03$ & $3.51 \mathrm{E}-03$ & 3.105 & 1.44 & 1.08 \\
\hline 2 & 2.53 & 1.17 & 0.88 & $9.00 \mathrm{E}-03$ & $3.40 \mathrm{E}-03$ & $2.87 \mathrm{E}-03$ & 2.531 & 1.18 & 0.88 \\
\hline 3 & 2.25 & 1.04 & 0.78 & $8.00 \mathrm{E}-03$ & $3.02 \mathrm{E}-03$ & $2.55 \mathrm{E}-03$ & 2.25 & 1.04 & 0.78 \\
\hline 4 & 3.09 & 1.43 & 1.07 & $1.10 \mathrm{E}-02$ & $4.15 \mathrm{E}-03$ & $3.51 \mathrm{E}-03$ & 3.094 & 1.44 & 1.08 \\
\hline 5 & 4.05 & 1.88 & 1.41 & $1.44 \mathrm{E}-02$ & $5.43 \mathrm{E}-03$ & $4.60 \mathrm{E}-03$ & 4.05 & 1.88 & 1.41 \\
\hline 6 & 2.53 & 1.17 & 0.88 & $9.00 \mathrm{E}-03$ & $3.40 \mathrm{E}-03$ & $2.87 \mathrm{E}-03$ & 2.531 & 1.18 & 0.88 \\
\hline 7 & 3.15 & 1.46 & 1.09 & $1.12 \mathrm{E}-02$ & $4.23 \mathrm{E}-03$ & $3.58 \mathrm{E}-03$ & 3.15 & 1.46 & 1.1 \\
\hline 8 & 2.98 & 1.38 & 1.04 & $1.06 \mathrm{E}-02$ & $4.00 \mathrm{E}-03$ & $3.38 \mathrm{E}-03$ & 2.981 & 1.38 & 1.04 \\
\hline 9 & 3.04 & 1.41 & 1.05 & $1.08 \mathrm{E}-02$ & $4.07 \mathrm{E}-03$ & $3.45 \mathrm{E}-03$ & 3.038 & 1.41 & 1.06 \\
\hline 10 & 2.93 & 1.35 & 1.02 & $1.04 \mathrm{E}-02$ & $3.92 \mathrm{E}-03$ & $3.32 \mathrm{E}-03$ & 2.925 & 1.36 & 1.02 \\
\hline 11 & 3.21 & 1.48 & 1.11 & $1.14 \mathrm{E}-02$ & $4.30 \mathrm{E}-03$ & $3.64 \mathrm{E}-03$ & 3.206 & 1.49 & 1.12 \\
\hline 12 & 3.09 & 1.43 & 1.07 & $1.10 \mathrm{E}-02$ & $4.15 E-03$ & $3.51 \mathrm{E}-03$ & 3.094 & 1.44 & 1.08 \\
\hline 13 & 2.36 & 1.09 & 0.82 & $8.40 \mathrm{E}-03$ & $3.17 \mathrm{E}-03$ & $2.68 \mathrm{E}-03$ & 2.363 & 1.1 & 0.82 \\
\hline 14 & 2.25 & 1.04 & 0.78 & $8.00 \mathrm{E}-03$ & $3.02 \mathrm{E}-03$ & $2.55 \mathrm{E}-03$ & 2.25 & 1.04 & 0.78 \\
\hline 15 & 2.48 & 1.15 & 0.86 & $8.80 \mathrm{E}-03$ & $3.32 \mathrm{E}-03$ & $2.81 \mathrm{E}-03$ & 2.475 & 1.15 & 0.86 \\
\hline 16 & 2.53 & 1.17 & 0.88 & $9.00 \mathrm{E}-03$ & $3.40 \mathrm{E}-03$ & $2.87 \mathrm{E}-03$ & 2.531 & 1.18 & 0.88 \\
\hline 17 & 2.53 & 1.17 & 0.88 & $9.00 \mathrm{E}-03$ & $3.40 \mathrm{E}-03$ & $2.87 \mathrm{E}-03$ & 2.531 & 1.18 & 0.88 \\
\hline 18 & 2.53 & 1.17 & 0.88 & $9.00 \mathrm{E}-03$ & $3.40 \mathrm{E}-03$ & $2.87 \mathrm{E}-03$ & 2.531 & 1.18 & 0.88 \\
\hline 19 & 2.81 & 1.3 & 0.98 & $1.00 \mathrm{E}-02$ & $3.77 \mathrm{E}-03$ & $3.19 \mathrm{E}-03$ & 2.813 & 1.31 & 0.98 \\
\hline 20 & 2.25 & 1.04 & 0.78 & $8.00 \mathrm{E}-03$ & $3.02 \mathrm{E}-03$ & $2.55 \mathrm{E}-03$ & 2.25 & 1.04 & 0.78 \\
\hline 21 & 2.53 & 1.17 & 0.88 & $9.00 \mathrm{E}-03$ & $3.40 \mathrm{E}-03$ & $2.87 \mathrm{E}-03$ & 2.531 & 1.18 & 0.88 \\
\hline 22 & 2.42 & 1.12 & 0.84 & $8.60 \mathrm{E}-03$ & $3.24 \mathrm{E}-03$ & $2.75 \mathrm{E}-03$ & 2.419 & 1.12 & 0.84 \\
\hline 23 & 2.81 & 1.3 & 0.98 & $1.00 \mathrm{E}-02$ & $3.77 \mathrm{E}-03$ & $3.19 \mathrm{E}-03$ & 2.813 & 1.31 & 0.98 \\
\hline 24 & 2.81 & 1.3 & 0.98 & $1.00 \mathrm{E}-02$ & $3.77 \mathrm{E}-03$ & $3.19 \mathrm{E}-03$ & 2.813 & 1.31 & 0.98 \\
\hline 25 & 2.81 & 1.3 & 0.98 & $1.00 \mathrm{E}-02$ & $3.77 \mathrm{E}-03$ & $3.19 \mathrm{E}-03$ & 2.813 & 1.31 & 0.98 \\
\hline 26 & 3.21 & 1.48 & 1.11 & $1.14 \mathrm{E}-02$ & $4.30 \mathrm{E}-03$ & $3.64 \mathrm{E}-03$ & 3.206 & 1.49 & 1.12 \\
\hline 27 & 2.19 & 1.02 & 0.76 & $7.80 \mathrm{E}-03$ & $2.94 \mathrm{E}-03$ & $2.49 \mathrm{E}-03$ & 2.194 & 1.02 & 0.76 \\
\hline 28 & 1.97 & 0.91 & 0.68 & $7.00 \mathrm{E}-03$ & $2.64 \mathrm{E}-03$ & $2.23 \mathrm{E}-03$ & 1.969 & 0.91 & 0.69 \\
\hline 29 & 2.48 & 1.15 & 0.86 & $8.80 \mathrm{E}-03$ & $3.32 \mathrm{E}-03$ & $2.81 \mathrm{E}-03$ & 2.475 & 1.15 & 0.86 \\
\hline 30 & 2.48 & 1.15 & 0.86 & $8.80 \mathrm{E}-03$ & $3.32 \mathrm{E}-03$ & $2.81 \mathrm{E}-03$ & 2.475 & 1.15 & 0.86 \\
\hline 31 & 2.48 & 1.15 & 0.86 & $8.80 \mathrm{E}-03$ & $3.32 \mathrm{E}-03$ & $2.81 \mathrm{E}-03$ & 2.475 & 1.15 & 0.86 \\
\hline 32 & 2.25 & 1.04 & 0.78 & $8.00 \mathrm{E}-03$ & $3.02 \mathrm{E}-03$ & $2.55 \mathrm{E}-03$ & 2.25 & 1.04 & 0.78 \\
\hline 33 & 2.25 & 1.04 & 0.78 & $8.00 \mathrm{E}-03$ & $3.02 \mathrm{E}-03$ & $2.55 \mathrm{E}-03$ & 2.25 & 1.04 & 0.78 \\
\hline 34 & 2.53 & 1.17 & 0.88 & $9.00 \mathrm{E}-03$ & $3.40 \mathrm{E}-03$ & $2.87 \mathrm{E}-03$ & 2.531 & 1.18 & 0.88 \\
\hline 35 & 2.36 & 1.09 & 0.82 & $8.40 \mathrm{E}-03$ & $3.17 \mathrm{E}-03$ & $2.68 \mathrm{E}-03$ & 2.363 & 1.1 & 0.82 \\
\hline 36 & 3.09 & 1.43 & 1.07 & $1.10 \mathrm{E}-02$ & $4.15 \mathrm{E}-03$ & $3.51 \mathrm{E}-03$ & 3.094 & 1.44 & 1.08 \\
\hline 37 & 3.09 & 1.43 & 1.07 & $1.10 \mathrm{E}-02$ & $4.15 \mathrm{E}-03$ & $3.51 \mathrm{E}-03$ & 3.094 & 1.44 & 1.08 \\
\hline Min & 1.97 & 0.91 & 0.68 & $7.00 \mathrm{E}-03$ & $2.64 \mathrm{E}-03$ & $2.23 \mathrm{E}-03$ & 1.97 & 0.91 & 0.69 \\
\hline Max & 4.05 & 1.88 & 1.41 & $1.44 \mathrm{E}-02$ & $5.43 \mathrm{E}-03$ & $4.60 \mathrm{E}-03$ & 4.05 & 1.88 & 1.41 \\
\hline AVG & 2.69 & 1.24 & 0.93 & $9.56 \mathrm{E}-03$ & $3.61 \mathrm{E}-03$ & $3.05 \mathrm{E}-03$ & 2.69 & 1.25 & 0.94 \\
\hline \%Affected & $30 \%$ & $30 \%$ & $22 \%$ & $0 \%$ & $0 \%$ & $0 \%$ & $100 \%$ & $97 \%$ & $32 \%$ \\
\hline
\end{tabular}

and aquifer material, which was further affected by the evaporation process. One of the most important elements impacting groundwater quality is its geological location. The Gibbs diagram explains about the origin source of the chemical elements in the groundwater. This diagram plotted $\mathrm{x}$-axis $(\mathrm{Na}+\mathrm{k} / \mathrm{Na}+\mathrm{k}+\mathrm{CA})$ and $\mathrm{y}$-axis TDS values. All the groundwater samples were fallen on the rock-water interaction area. 


\section{Conclusion}

One of the most pressing issues in Nellore's urban region has been fluoride and nitrate contamination. The increased concentration geochemical parameters were PH, EC, TDS, and nitrate, with $10 \%$ of groundwater samples above the drinking water acceptable limit. Fluoride in the study area fell in the permissible limit and the total health index on human beings the various stages. All the THI values are $<1$; therefore, there is no significance in the study area population. A total of $99 \%$ nitrates in groundwater samples were exceeding the permissible limit. The total hazard index of the various ages was calculated, and the affected percentages were children (100\%), women (95\%), and men (35\%). The nitrate and fluoride were released due to the rock-water interaction, nitrification processes, fertilizer, pesticides, and dissolution of the mineral deposit like fluorite apatite, rocklike hornblende granite schist, and mica schist. The Gibbs diagram explains the origin source of chemical elements in the study area. Overall, from this research, the study area population severely fell in a problem with nitrate contamination, and fluoride has no significant effect. These researches suggest that before consumption of the water, proper treatment is necessary.

\section{Funding Not Applicable.}

Data Availability The raw data are obtained from NRSC Bhuvan and USGS website (https://bhuvan.nrsc.gov.in/ and https://earthexplorer. usgs.gov/) which is available free of cost, and the findings of this study are available from the corresponding author, upon reasonable request.

\section{Declarations}

Conflict of interest The authors declare that they have no known competing financial interests or personal relationships which have or could be perceived to have influenced the work reported in this article.

Open Access This article is licensed under a Creative Commons Attribution 4.0 International License, which permits use, sharing, adaptation, distribution and reproduction in any medium or format, as long as you give appropriate credit to the original author(s) and the source, provide a link to the Creative Commons licence, and indicate if changes were made. The images or other third party material in this article are included in the article's Creative Commons licence, unless indicated otherwise in a credit line to the material. If material is not included in the article's Creative Commons licence and your intended use is not permitted by statutory regulation or exceeds the permitted use, you will need to obtain permission directly from the copyright holder. To view a copy of this licence, visit http://creativecommons.org/licenses/by/4.0/.

\section{References}

Adimalla N (2019) Spatial distribution, exposure, and potential health risk assessment from nitrate in drinking water from the semi-arid region of South India. Human Ecol Risk Assessment Int J.

Adimalla N (2021) Application of the entropy weighted water quality index (EWQI) and the pollution index of groundwater (PIG) to assess groundwater quality for drinking purposes: a case study in a rural area of Telangana State. India Arch Environ Contam Toxicol 80:31-40. https://doi.org/10.1007/s00244-020-00800-4

Adimalla N, Qian H (2021) Groundwater chemistry, distribution and potential health risk appraisal of nitrate enriched groundwater: A case study from the semi-urban region of South India. Ecotoxicol. Environ. Saf. 207:111277

Adimalla N, Qian H, Li P (2019) Entropy water quality index and probabilistic health risk assessment from the geochemistry of groundwaters in hard rock terrain of Nanganur County, South India. Geochemistry. https://doi.org/10.1016/j.chemer.2019. 125544

Agoubi B, Kharroubi A, Abida H (2013) Hydrochemistry of groundwater and its assessment for irrigation purposes in coastal Jeffara Aquifer, southeastern Tunisia. Arab J Geosci 6:1163-1172

Alimohammadi M, Latifi N, Nabizadeh R, Yaghmaeian K, Mahvi AH, Yousefi M, Foroohar P, Hemmati S, Heidarinejad Z (2018) Determination of nitrate concentration and its risk assessment in bottled water in Iran. Data Brief 19:2133-2138

Aravinthasamy P, Karunanidhi D, Subramani T, Srinivasamoorthy K, Anand B (2020) Geochemical evaluation of fluoride contamination in groundwater from Shanmuganadhi River basin, South India: implication on human health. Environ Geochem Health 42(7):1937-1963

Balaji E, Nagaraju A, Sreedhar Y et al (2017) Hydrochemical characterization of groundwater in around Tirupati Area, Chittoor District, Andhra Pradesh. South India Appl Water Sci 7:1203-1212

BIS (2012) Indian standard specifications for drinking water. IS:10500, Bureau of Indian Standards, New Delhi, India

Darvishmotevalli M, Moradnia M, Noorisepehr M, Fatehizadeh A, Fadaei S, Mohammadi H, Salari M, Jamali HA, Daniali SS (2019) Evaluation of carcinogenic risks related to nitrate exposure in drinking water in Iran. MethodsX. 6:17161727

Fang J, Lyon DY, Wiesner MR, Dong J, Alvarez PJ (2007) Effect of a fullerene water suspension on bacterial phospholipids and membrane phase behavior. Environ Sci Technol 41(7):2636-2642

Garg VK, Suthar S, Singh S et al (2009) Drinking water quality in villages of southwestern Haryana, India: assessing human health risks associated with hydrochemistry. Environ Geol 58:1329-1340

Gevera P, Mouri H, Maronga G (2019) Occurrence of fluorosis in a population living in a high-fluoride groundwater area: Nakuru area in the Central Kenyan Rift Valley. Environ Geochem Health 41(2):829-840. https://doi.org/10.1007/s10653-018-0180-2

Golla V et al (2020) Assessment of Groundwater Contamination with Emphasis on Sulfates, Barites Mining Area, Mangampeta, Andhra Pradesh, India. In: Babu K, Rao H, Amarnath Y (eds) Emerging Trends in Civil Engineering Lecture Notes in Civil Engineering, vol 61. Springer, Singapore. https://doi.org/10.1007/978-981-151404-3_26

Jasmin I, Mallikarjuna P (2013) Physicochemical quality evaluation of groundwater and development of drinking water quality index for Araniar River Basin. Environ Monit Assess, Tamil Nadu.

Kimambo V, Bhattacharya P, Mtalo F, Mtamba J, Ahmad A (2019) Fluoride occurrence in groundwater systems at global scale and status of defluoridation-state of the art. Groundwater Sustain Dev 9:100223 
Kundu N, Panigrahi MK, Tripathy S et al (2001) Geochemical appraisal of fluoride contamination of groundwater in the Nayagarh District of Orissa, Indian. Environ Geol 41:451-460

Li P, He X, Li Y, Xiang G (2018) Occurrence and health implication of fluoride in groundwater of loess aquifers in the Chinese Loess Plateau: a case study of Tongchuan, northwest China. Expo Health.

Mirzaei PA (2015) Recent challenges in modeling of the urban heat island. Sustain Cities Soc 19:200-206

Monjerezi M, Vogt RD, Aagaard P, Saka JDK (2012) The hydro-geochemistry of groundwater resources in an area with prevailing saline groundwater, lower Shire Valley, Malawi. J African Earth Sci 68:67-81

Muralidhara RB, Sunitha V (2020) Geochemical and health risk assessment of fluoride and nitrate toxicity in semi-arid-region of Anantapur District, South India. Environ Chem Ecotoxicol 2:150161

Nagaraju A, Balaji E, Thejaswi A, Sun L (2015) Quality evaluation of groundwater in Mulakalacheruvu area, Chittoor District, Andhra Pradesh, South India based on hydrogeochemistry. Fres Env Bull 24:4496-4503

Nagaraju A, Thejaswi A, Sreedhar Y (2016) Assessment of Groundwater Quality of Udayagiri area, Nellore District, Andhra Pradesh, South India Using Multivariate Statistical Techniques. Earth Sci Res J 20(4):E1-E7

Narsimha A, Rajitha S (2018) Spatial distribution and seasonal variation in fluoride enrichment in groundwater and its associated human health risk assessment in Telangana State, South India. Hum Ecol Risk Assess Int J. https://doi.org/10.1080/10807039. 2018.1438176

Narsimha A, Sudarshan V (2017) Contamination of fluoride in groundwater and its effect on human health: a case study in hard rock aquifers of Siddipet, Telangana State. India Appl Water Sci $7: 2501-2512$

Onipe T, Edokpayi JN, Odiyo JO (2020) A review on the potential sources and health implications of fluoride in groundwater of SubSaharan Africa. J Environ Sci Health A Tox Hazard Subst Environ Eng 55(9):1078-1093

Petalas CP, Diamantis IB (1999) Origin and distribution of saline groundwaters in the upper Miocene aquifer system, coastal Rhodope area, northeastern Greece. Hydrogeol J 7:305-316

Rahmati O, Samani AN, Mahmoodi N, Mahdavi M (2014) Assessment of the contribution of $\mathrm{N}$-fertilizers to nitrate pollution of groundwater in Western Iran (case study: Ghorveh-Dehgelan aquifer). Water Qual Expo Health 7(2):143-151
Rezaei H, Jafari A, Kamarehie B, Fakhri Y (2018) Health risk assessment related to the fluoride, and nitrate in the drinking water in the Sanandaj. Kurdistan CountyIron Hum Ecol Risk Assess 5(2018):1242-1250

Rezvani Ghalhari M, Kalteh S, Asgari Tarazooj F, Zeraatkar A, Mahvi AH (2021) Health risk assessment of nitrate and fluoride in bottled water: a case study of Iran. Environ Sci Pollut Res Int

Sharma BS (1999) A study on water quality of river Yamuna at Agra. Indian J Environ Prot 19(6):440-441

Shirke KD, Kadam A, Pawar NJ (2021) Health risk assessment and prevalence of fluoride in groundwater around the geological diversity of Ambadongar South Gujarat, India. Human Ecol Risk Assessment Int J 27(6): 1523-1542

Subba Rao N, Chaudhary M (2019) Hydrogeochemical processes regulating the spatial distribution of groundwater contamination, using pollution index of groundwater (PIG) and hierarchical cluster analysis (HCA): a case study,

Veeraswamy G, Nagaraju A, Balaji E, Sreedhar Y, Rajasekhar M (2018) Water quality assessment in terms of water quality index in Gudur area, Nellore District, Andhra Pradesh. Int J Tech Res Sci 3(1):34-39

Xiao J, Jin Z, Zhang F (2015G) Geochemical controls on fluoride concentrations in natural waters from the middle Loess Plateau, China. J Geochem Explor 159:252-261

Yadav KK, Gupta N, Kumar V, Khan SA, Kumar A (2018) A review of emerging adsorbents and current demand for defluoridation of water: bright future in water sustainability. Environ Int 111:80-108

Yu G, Wang J, Liu L et al (2020) The analysis of groundwater nitrate pollution and health risk assessment in rural areas of Yantai. China BMC Public Health 20:437

Zhou X, Shen Y, Zhang H et al (2015) Hydrochemistry of the naturally low $\mathrm{pH}$ groundwater in the coastal aquifers near Beihai. China J Ocean Univ China 14:475-483. https://doi.org/10.1007/ s11802-015-2631-z

Publisher's Note Springer Nature remains neutral with regard to jurisdictional claims in published maps and institutional affiliations. 